\title{
An update: the role of Nephrin inside and outside the kidney
}

\author{
LI XueZhu ${ }^{1} \&$ HE John Cijiang ${ }^{2 *}$ \\ ${ }^{1}$ Department of Nephrology; Shanghai East Hospital, Tongji University School of Medicine, Shanghai 200120, China; \\ ${ }^{2}$ Department of Medicine/Nephrology, Icahn School of Medicine at Mount Sinai, New York, NY 10029, USA
}

Received December 23, 2014; accepted February 27, 2015; published online April 15, 2015

\begin{abstract}
Nephrin is a key molecule in podocytes to maintain normal slit diaphragm structure. Nephin interacts with many other podocyte and slit diaphragm protein and also mediates important cell signaling pathways in podocytes. Loss of nephrin during the development leads to the congenital nephrotic syndrome in children. Reduction of nephrin expression is often observed in adult kidney diseases including diabetic nephropathy and HIV-associated nephropathy. The critical role of nephrin has been confirmed by different animal models with nephrin knockout and knockdown. Recent studies demonstrate that knockdown of nephrin expression in adult mice aggravates the progression of unilateral nephrectomy and Adriamycin-induced kidney disease. In addition to its critical role in maintaining normal glomerular filtration unit in the kidney, nephrin is also expressed in other organs. However, the exact role of nephrin in kidney and extra-renal organs has not been well characterized. Future studies are required to determine whether nephrin could be developed as a drug target to treat patients with kidney disease.
\end{abstract}

Nephrin, podocytes, kidney, slit diaphragm, proteinuria, cell signaling pathway

Citation: $\quad$ Li XZ, He JC. An update: the role of Nephrin inside and outside the kidney. Sci China Life Sci, 2015, 58: 649-657, doi: 10.1007/s11427-015-4844-1

The filtration property of the kidney localizes to the glomerular capillary wall, which forms a specialized filter that allows the passage of small plasma molecules, including water and waste products, from the circulating blood into the primary urine for excretion. This filtration barrier consists of three layers: the fenestrated endothelium, glomerular basement membrane (GBM) and podocytes. Podocytes enclose the outer aspect of the glomerular capillary wall and is the final barrier to filtration. Cytoplasmic extensions of the podocytes, called foot processes (FP), interdigitate each other from adjacent podocytes. Specialized cell-cell junctions between the FP, called slit diaphragms (SD), form a zipper-like structure that functions as a sieve to restrict the passage of large molecules.

Nephrin, an integral transmembrane protein of the immunoglobulin superfamily, is the first protein identified in the SD in 1998 [1]. Nephrin has crucial functions both in

*Corresponding author (email: cijiang.he@mssm.edu) controlling the podocyte SD structure and as a hub of signaling pathways. Although many years' research efforts have been made, we are still far from having a complete understanding of nephrin's role in podocyte as well as in other cell types. In this paper, we will review research progress related to the role of nephrin both inside and outside of the kidney.

\section{Molecular structure of nephrin}

NPHS1, gene that code Nephrin, was first cloned in 1998 by Kestilä and colleagues [1]. NPHS1 is assigned to the long arm of chromosome 19,19q13.1, with a telomere-tocentromere orientation [1,2]. The size of NPHS1 gene is 26 $\mathrm{kb}$ and it contains totally 29 exons. Northern hybridization and in situ hybridization suggest that NPHS1 is mostly localized in the glomerulus but also found in the brain, pancreas, testis, heat, spleen and lymphoid tissues. 
Nephrin is a transmembrane protein with 1,241 residues and a calculated molecular weight of $135 \mathrm{kD}$ without posttranslational modifications [1]. Nephrin composes of an extracellular domain containing eight IgG-like modules and one fibronectin type III-like motif, a single transmembrane domain and a short intracellular domain containing nine tyrosines. The IgG-like domains are of type $\mathrm{C} 2$ which is typically found in proteins participating in cell-cell [3-5] and cell-matrix interactions [6]. Nephrin has two cysteine residues in each IgG-like domain, which can form disulfide bridges between Nephrin molecules or with other proteins $[1,7]$, leading to either homophilic interaction of Nephrin molecules or heterophilic interactions of Nephrin with other SD proteins.

In sodium dodecyl sulfate-polyacrylamide gel electrophoresis (SDS-PAGE) analysis, Nephrin runs as a 185-200 $\mathrm{kD}$ protein doublet suggesting posttranslational modifications $[8,9]$. In the extracellular domain of Nephrin there are 10 potential sites for $\mathrm{N}$-glycosylation [1] and glycosylation of Nephrin is critical for its proper folding and localization in the plasma membrane [10].

Several spliced variants of Nephrin have been identified in both rats and humans. Nephrin- $\alpha$, MW $166 \mathrm{kD}$, lacks the nucleotides 3167-3286 of exon 24, which codes the transmembrane spanning domain, produces a truncated soluble form of Nephrin. The function of Nephrin- $\alpha$ is still unknown [11,12].

\section{Location of Nephrin in the glomerulus}

In kidney, Nephrin exists exclusively at the filtration areas of the podocyte foot processes in glomerulus [13]. Nephrin molecules were proposed to interact in the slit through homophilic and heterophilic interactions of Nephrin with itself and with Neph family proteins forming a porous substructure in the SD. Nephrin mRNA was first detected in the late $\mathrm{S}$-shaped bodies during the kidney development. Nephrin mRNA also shows a typical splicing pattern apparently regulated differently in various disease entities [11]. Nephrin mRNA has a very unique regulation by natural antisense mRNA [14] and bidirectional regulation with a closely related molecule, filtrin [15].

Nephrin is also expressed in pronephric glomerulus of zebrafish and medaka in which Nephrin needs to be integrated to the membrane before the formation of the SD and moving to the proper site to form the SD [16]. Nephrin is absent in the slit diaphragms of birds. Birds have larger SD as compared with mammalian glomeruli [17], and the genome of birds does not contain a coding sequence for Nephrin [18]. Birds excrete nitrogen mainly in the form of uric acid, which is not completely soluble in water and requires a certain amount of proteins to be maintained in a colloidal suspension in the urine. Due to the absence of Nephrin, proteins could pass the glomerular filtration barrier.
This is an indirect evidence to support the importance of Nephrin in mammals.

\section{Regulation of Nephrin expression}

\subsection{Interaction with the other SD proteins}

Loss of Nephrin does not affect podocyte viability, suggesting that Nephrin can be compensated by other podocyte molecules during glomerular development [19]. Nephrin can interact with the cytoskeleton through several proteins, but the relationship between Nephrin and the other podocyte molecules has not been fully demonstrated.

\subsubsection{CD2 adaptor protein (CD2AP)}

$\mathrm{CD} 2 \mathrm{AP}$ is an intracellular protein initially found in T-lymphocyte molecule CD2. In glomerulus, CD2AP is also located at the SD and it can interact with Nephrin via its C-terminal domain [20,21]. CD2AP is an adaptor protein that is also important for the maintenance of the SD. The $\mathrm{N}$-terminal domain of CD2AP can bind to p85 and facilitate the Nephrin-induced AKT signaling [22], which protects podocytes from apoptosis. CD2AP enhanced the small ubiquitin-related modification of CIN85, which increase the binding of CIN85 to Nephrin [23], induces Nephrin ubiquitination and endocytosis [24].CD2AP knockout $\left(\mathrm{CD} 2 \mathrm{AP}^{-/-}\right)$ mice are born healthy but develop a rapid-onset nephrotic syndrome at three weeks of age and die of renal failure at six weeks [21,25]. Kidneys from $\mathrm{CD} 2 \mathrm{AP}^{-/-}$mice initially exhibit normal Nephrin localization, but with aging the FP become effaced [26] and deficiency of CD2AP leads to a loss of expression of the SD protein Nephrin in podocytes.

\subsubsection{Podocin}

Podocin has been shown to be expressed only in the podocytes, and serve as a scaffolding protein in the SD complex. Podocin is an integral membrane protein with both $\mathrm{N}$ and C-terminal domains directed into cytosol. Podocin associates via its $\mathrm{C}$-terminal domain with cytoplasmic part of Nephrin at the specialized lipid raft microdomains of the plasma membrane [27,28]. NPHS2, the gene that codes podocin, is mutated in autosomal recessive steroid-resistant nephrotic syndrome and has a similar phenotype of CNF. Podocin-deficient mice also develop proteinuria during ear-

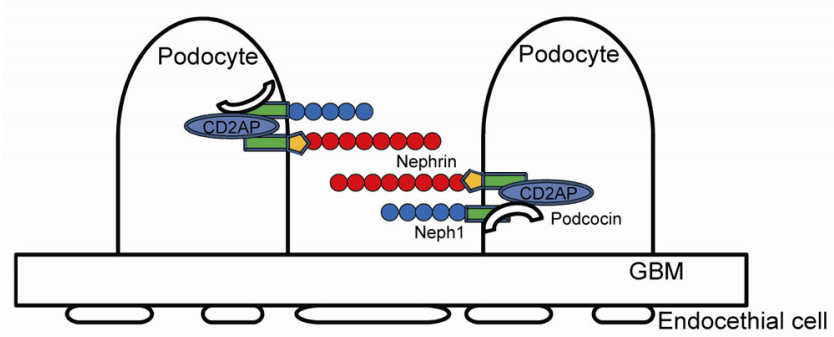

Figure 1 (color online) Location of Nephrin in podocyte. 
ly antenatal period, and die in the five weeks after birth. Electron microscopy showed fusion of foot processes and massive mesangial sclerosis with vastly reduced Nephrin expression [29]. Podocin can recruit Nephrin into lipid rafts, connect via its C-terminal domain with CD2AP and then activate mitogen-activated protein kinase cascades [22,28]. And knocking down podocin expression in a cultured podocyte cell line by mRNA interference decreased Nephrin expression by $70 \%$ and altered Nephrin localization from the membrane surface to the nuclear area [30].

\subsubsection{Neph proteins}

The Neph protein family comprises three members: Neph1, Neph2 and Neph3. They belong to the immunoglobulin superfamily and are composed of a short intracellular domain and an extracellular domain with five Ig-like motifs $[31,32]$. Neph1 is a protein with weak homology and structural similarity to Nephrin.Neph1 can form a heterophilic interaction with Nephrin, via cis- or trans-interactions at the podocyte intercellular junction. [33,34]. The dissociation of Neph1 from Nephrin induced proteinuria in FSGS [35]. The Neph1-Nephrin complex cooperate to induce actin filament nucleation and elongation in a tyrosine phosphorylation dependent fashion at the plasma membrane by recruiting the cytoskeletal adaptor protein Nck1/2 and other proteins of the actin polymerization complex [36,37]. The lack of Neph1 leads to prenatal lethality with proteinuria and podocyte foot processes effacement in Neph1 knockout mice [38]. Neph1 also interacts with other SD proteins like podocin [39] and ZO-1 [40].

Neph2 can also form homodimers and interacts specifically with the extracellular domain of Nephrin both in vitro and in vivo. The extracellular domain of Neph2 is cleaved under physiological conditions [41]. Neph3 is a pleiotropic gene active during distinct stages of tissue differentiation and associates directly with the regulation of both glomerular and neural development [42].

\subsubsection{Zonula occludens-1 (ZO-1)}

$\mathrm{ZO}-1$ is a tight junction protein in the cytoplasmic base of SD. In diabetes, ZO-1 expression decreases and redistributes from podocyte membrane to the cytoplasm [43]. The lack of Nephrin does not affect the expression of ZO-1 in mice. However, injection of antibodies against p51 antigen, an epitope of Nephrin molecule, induces nephrosis in rats and leads to progressive decline of ZO-1. It was recently shown that ZO-1 may serve as a cytoplasmic organizer by coupling the Nephrin-Neph1 complex to the actin cytoskeleton and recruiting appropriate signal transduction components to the SD area $[9,44,45]$.

\subsubsection{Alpha-actin 4 (ACTN4)}

The alpha-actinin-4 is an actin-bundling protein [46], and ubiquitously expressed. Mutations in ACTN4 lead to an inheritable form of glomerulosclerosis [46]. In alpha- actinin-4 mutant mice, Nephrin mRNA and protein levels were significantly reduced [47]. In vitro, silencing of Nephrin, using RNAi, did not change the expression of alpha-actinin-4, but silencing of alpha-actinin-4 downregulated Nephrin and upregulated podocin and CD2AP expression [48].

\subsection{Nephrin-mediated intracellular signaling pathways}

Besides the important role in scaffolding of SD, Nephrin also serves as a "signaling node" in the SD by transmitting extracellular domain from the SD to the intracellular actin cytoskeleton $[27,49,50]$. Nephrin has the nine tyrosine residues in the intracellular domain, some of which are phosphorylated after ligand binding [51] and could serve as docking sites for $\mathrm{SH} 2$ domain-containing kinase and adaptor proteins.

\subsubsection{PI3K/AKT pathway}

The phosphorylated Nephrin can bind to the p85 regulatory subunit of phosphoinositide 3-OH kinase (PI3K), allowing the catalytic subunit p110 to act on the phospholipids of inner leaflet of the cell membrane, then stimulating the serine-threonine kinase AKT, which controls cell growth, migration, and survival [22]. Bad is one of the downstream target proteins of AKT. Bad interacts with pro-survival Bcl2 family members to promote apoptosis. Phosphorylation of Bad protects podocytes against detachment-induced podocyte apoptosis [22].

\subsubsection{Nck}

Nephrin can bind to the Nck adaptor proteins after the phosphorylation by the Src-family tyrosine kinase Fyn. Nephrin-Nck interaction regulates FP morphology and actin dynamics and is important for podocyte FP development and repair after injury. Nck proteins contain one $\mathrm{SH} 2$ and three $\mathrm{SH} 3$ domains. The $\mathrm{SH} 2$ domain of Nck binds to phosphotyrosine residues of Nephrin, and the SH3 domain recruits other proteins involved in actin cytoskeleton regulation. Recently it has been shown that inducible deletion of Nck1 and 2 in the podocytes of adult mice results in proteinuria and reduces phosphorylation of Nephrin [36,52].

\subsubsection{PKC}

$\mathrm{PKC} \alpha$ is a Nephrin binding protein, and sequence analysis of the Nephrin intracellular domain predicted a PKC recognition motif. In diabetic nephropathy, Nephrin internalization is accelerated through regulation of the $\beta$-arrestin2Nephrin interaction by PKC $\alpha$. PKC $\alpha$ can induce the binding of phosphorylated threonine residues 1120 and 1125 of Nephrin with $\beta$-arrestin2 $[53,54]$. Recently, Satoh and colleagues [55] have shown that the turnover rates of Nephrin was up-regulated by atypical protein kinase $\mathrm{C}$ (aPKC).

\subsubsection{Calcium signalling}

Nephrin plays a crucial role in the regulation of podocyte 


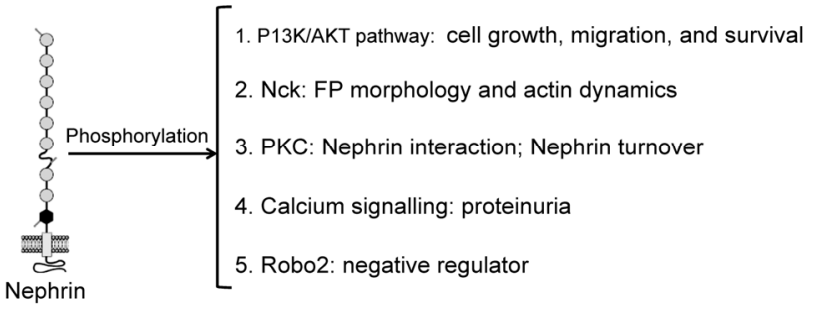

Figure 2 Nephrin-mediated intracellular signaling pathways.

calcium homeostasis. Phosphorylation of Nephrin at Tyr1204 can recruit and activate phospholipase C- $\gamma 1$ (PLC- $\gamma 1$ ), and then triggers a rapid $\left[\mathrm{Ca}^{2+}\right]_{\mathrm{i}}$ influx in podocyte [56].

\subsubsection{Others}

Roundabout (Robo) family proteins are cell surface receptors. Recently Robo2 has been shown to be expressed at the basal surface of podocytes and co-localizes with Nephrin and podocin. Robo2 signaling acts as a negative regulator on Nephrin signaling. Robo2 interacts directly with adaptor protein Nck and forms a complex with Nephrin, thereby inhibiting actin polymerization induced by Nephrin [57].

\section{Clinic features of Nephrin deficiency}

\subsection{Nephrin in congenital nephrotic syndrome of Finn- ish type}

Mutations in the NPHS1 gene cause congenital nephrotic syndrome of the Finnish type (CNF). The nephrotic syndrome progresses rapidly after birth and patients die within the first two years of life. CNF has an incidence of 1:10,000 births in Finland, and an autosomal recessive mode of inheritance. Two mutations, named $\mathrm{Fin}_{\text {major }}$ and $\mathrm{Fin}_{\text {minor }}$, were found in over $90 \%$ of CNF patients. The Fin ${ }_{\text {major }}$ is a deletion (CT) in exon 2, which causes a frameshift and the formation of stop codon at the end of exon 2. This mutation leads to a complete lack of Nephrin protein. Fin ${ }_{\text {minor }}$ is a nonsense mutation $(C \rightarrow T)$ in exon 26 , leading to a truncated nephrin protein with 1109-residues [1,2].

The most classic clinic manifestation of CNF is heavy proteinuria, which begins in utero, along with hypoproteinemia and edema. The other abnormal findings include prematurity and large placenta. The clinical features of patients with Fin ${ }_{\text {major }}$ and Fin $_{\text {minor }}$ mutations are similar. Therapies with agents to reduce the glomerular filtration pressure have not been successful in reducing the proteinuria. Children with CNF are currently treated with bilateral nephrectomy and dialysis, followed by renal transplantation [58,59].

Under light microscopy, the kidney from patients with $\mathrm{CNF}$ is characterized by marked hyperplasia of mesangial cells, hyperlobulated capillary tufts, microcystic dilation of both proximal and distal tubuli, interstitial fibrosis and inflammation $[45,60]$. Diffuse podocyte foot process efface- ment, narrowing of the filtration slits and absence of slit-diaphragms are observed on electron microscopy, indicating that Nephrin is essential for the development of the SDs.

Recurrence of CNF occurs in $20 \%-25 \%$ of the patients after renal transplantation $[61,62]$. The recurrence of NS in $\mathrm{CNF}$ children appears only in patients with a $\mathrm{Fin}_{\text {major }} / \mathrm{Fin}_{\text {major }}$ homozygous genotype and in patients with high levels of serum anti-Nephrin antibodies, suggesting an autoimmune reaction against Nephrin.

\subsection{Nephrin expression in acquired kidney diseases}

Nephrin expression has been shown to be down-regulated in many human glomerular disease and animal models [63]. In addition, it has been noted in several human biopsy and animal studies that Nephrin is localized away from the slit diaphragm and changes from a linear capillary loop pattern to a granular cytoplasmic pattern in nephrotic disease.

\subsubsection{Primary nephrotic syndrome}

Furness et al. compared the expression of Nephrin in human samples of six normal kidneys and four specimens of nephrotic syndrome and found that Nephrin mRNA decreased in adult minimal change patients with nephrotic syndrome [64,65]. Nephrin staining is negative in sclerotic lesions in FSGS glomeruli, and in MN glomeruli with mesangial expansion. The expression of Nephrin was decreased only in the areas where the foot processes were effaced [66]. In the rat model of puromycin nephrosis, the glomerular Nephrin mRNA expression was diminished by $30 \%$ and $50 \%$ at days 3 and 8 after puromycin injection $[8,67]$. Nephrin expression was also reduced in the kidney of passive Heymann nephritis rats model [68], and in a PAN rat model $[65,69]$.

Nephrin expression in podocyte is correlated inversely with extent of glomerulosclerosis, but not with the amount of proteinuria. Urinary neph/AQP is increased in adult nephrotic syndrome (NS) patients, with the highest levels in FSGS patients [70].

However, some studies reported that expression of Nephrin did not change in proteinuric kidney disease [65,71]. Patrakka et al. [71] found that Nephrin mRNA and protein levels were similar between pediatric MCN patients and controls. Expression of Nephrin did not change in children proteinuric kidney disease such as MCN, FSGS, and MN. These studies suggest that the reduction of nephrin is not necessarily the underlying mechanism of proteinuria in these diseases.

\subsubsection{Nephrin expression in diabetic nephropathy}

Aaltonen et al. [72] showed that glomerular Nephrin expression was increased by 50\% in the STZ rats 4 weeks after induction of diabetes. Nephrin was found in the urine of the STZ-rats 4 to 6 weeks after induction of diabetes. However, in advanced DN, Nephrin expression seems to be 
reduced. Bonnet et al. [73] showed that induction of diabetes in spontaneously hypertensive rats by injection of STZ caused advanced DN together with significant reduction in glomerular Nephrin mRNA and protein levels. In human $\mathrm{DN}$, Nephrin mRNA was reduced in renal biopsy samples of T2DM patients compared to healthy controls by $62 \%$ $[74,75]$. Also a reduction in Nephrin protein levels has been reported in diabetic patients with microalbuminuria and nephrotic syndrome [76].

Nephrin expression is a marker of normal podocyte and the loss of podocytes correlating closely with disease progression [77]. It remains unclear whether reduction of nephrin in DN is second to loss of podocyte number or reduction of nephrin expression per podocyte.

\subsubsection{Other systemic and metabolic diseases}

Nephrin expression was absent in the sclerotic lesions and glomerular crescents of kidneys from patients with Henoch-Schonlein nephritis, lupus nephritis and some membranoproliferative glomerulonephritis. In lupus nephritis (LN), the reduction of Nephrin expression started from the early stage in the kidney of NZB/W LN mice. In patients with LN, nephrin was decreased particularly in diffuse proliferative LN and Nephrin expression correlates with disease severity in histology [78]. The levels of urinary nephrin excretion were increased in rheumatoid arthritis (RA) patients with nephropathie, and had a positive correlation with urinary protein concentrations [79].

\section{Nephrin deficient animal model for study}

\subsection{Nephrin knock-out (KO) mice model}

Nephrin KO mice were born at an expected Mendelian ratio, and seemingly normal at birth. But consistent with the human CNF disease phenotype, Nephrin homozygous KO mice develop edema and heavy non-selective proteinuria immediately after births, and die within $24 \mathrm{~h}$. The kidneys of the KO mice lacked Nephrin expression at both protein and mRNA levels. Similar to those in the glomeruli of CNF patients, these mice develop enlarged Bowman's spaces, dilated tubules, and effacement of podocyte foot process with the absence of SD. The glomerular ultrastructure of the heterozygotes Nephrin KO mice was identical to normal wild-type mice, indicating that one functional allele is enough to maintain the normal structure and function of podocyte SD [13].

In addition, podocyte-specific, doxycycline-induced transgenic expression of rat Nephrin in Nephrin KO mice successfully rescued the phenotype from perinatal death to normal morphology of podocytes and architecture of the SD [80]. Furthermore, KO of Nephrin in mice do not significantly affect the glomerular morphogenesis, podocyte viability or expression of other FPs and SD protein complex genes during development [19]. These data suggest that nephrin is critical for maintaining normal SD structure and prevent proteinuria. However, nephrin is not required for podocyte viability.

\subsection{Nephrin TRAP mice}

Rantanen and their colleagues generated a mutant Nphs1 mouse line by gene-trapping. Nephrin ${ }^{\text {trap/trap }}$ mutants show typical features of proteinuric disease and die soon after birth. Fibrotic glomeruli with distorted structures and cystic tubular lesions were found in the kidney. CD2AP and ZO-1 appeared unchanged as compared with the wild-type (wt) and Nephrin ${ }^{\text {wt/trap }}$. Electron microscopy revealed that $>90 \%$ of the podocyte foot processes were fused and slit diaphragms were missing. In Nephrin ${ }^{\text {wt/trap }}$, approximately $1 / 3$ of the FP were fused and Nephrin mRNA level decrease more than $60 \%$ [81].

\subsection{Anti-Nephrin antibody causes proteinuria in rats}

Injection of anti-Nephrin antibody (monoclonal antibody 5-1-6) in rats results in immediate proteinuria and foot process effacement. This antibody was recently shown to recognize an epitope of the extracellular domain of Nephrin [9]. The complement activation and leukocyte recruitment are absent in these rats. The glomerular histology remains intact except for partial retraction of the podocyte foot processes. The immediacy of proteinuria with relatively normal glomerular morphology in this rat model suggests that proteinuria is likely caused by binding of the antibody to the extracellular domain of Nephrin, thereby disrupting the molecular rearrangement of the slit diaphragm and permselectivity of the glomerular filtration barrier. The binding of this antibody can induce ligand endocytosis resulting in a loss of function or alteration of intracellular signaling mediated by Nephrin. The exact mechanism through which anti-Nephrin antibodies cause proteinuria in the mAb 5-1-6 nephropathy model remains to be determined [82].

\section{4 siRNA-mediated inducible depletion of Nephrin model}

Early perinatal lethality of conventional Nephrin KO mice makes it impossible to study the role of Nephrin in the adult kidney. We generated transgenic mice with doxycycline-inducible shRNA-mediated Nphsl knockdown using an in vivo RNA interference approach in our laboratory [83]. Our in vivo studies demonstrate that short-term Nephrin knockdown (6 weeks), starting after the completion of kidney development, had no impact on glomerular structure and function. In contrast, mice with chronic Nephrin knockdown (20 weeks) developed mild proteinuria, foot process effacement, filtration slit narrowing, mesangial hypercellularity and sclerosis, glomerular basement membrane thickening, subendothelial zone widening, and podocyte 
Table 1 Different Nephrin knock-out or knock-down animal model

\begin{tabular}{|c|c|c|c|}
\hline Animal model & Species & Generation method & Phenotype \\
\hline Coventional Nephrin KO & Mice & Homologous recombination & $\begin{array}{c}\text { Homozygous mice: massive proteinuria, nephrotic syndrome, } \\
\text { death soon after birth } \\
\text { Heterozygous mice have no phenotype }\end{array}$ \\
\hline Anti-Nephrin antibody & rat & $\begin{array}{l}\text { Inject anti-Nephrin monoclonal antibody } \mathrm{mAb} \\
5-1-6\end{array}$ & Immediate proteinuria and foot process effacement \\
\hline $\begin{array}{l}\text { siRNA-mediated Nephrin } \\
\text { knockdown }\end{array}$ & mice & siRNA interference approach & $\begin{array}{l}\text { Chronic long-time Nephrin knockdown results in mild pro- } \\
\text { teinuria, foot process effacement in adulthood }\end{array}$ \\
\hline
\end{tabular}

apoptosis.

When subjected to an acquired glomerular insult induced by either unilateral nephrectomy or Adriamycin, mice with short-term Nephrin knockdown developed more severe glomerular injury compared to those without Nephrin knockdown. AKT phosphorylation was markedly reduced in mice with chronic Nephrin knockdown. Our data provide the first direct experimental evidence suggesting that under the basal condition and in acquired glomerular diseases, Nephrin is required to maintain slit diaphragm integrity and slit diaphragm-mediated signaling to preserve glomerular function in adult mice.

\section{Nephrin expression in extra-renal organs}

Expression of Nephrin is not limited to the podocyte in kidney. Nephrin expression is also found in the testis, central nervous system (CNS), pancreas, placenta, heart and lymphoid tissue, indicating that Nephrin may have distinct functions in different tissues.

\subsection{CNS}

Nephrin is expressed in the fourth ventricle, spinal cord, cerebellum, hippocampus and olfactory bulb in the mouse brain during the development [13]. Recently, endogenous nephrin in adult rodent CNS had been found on the pons and corpus callosum and is expressed by granule cells and Purkinje cells of the cerebellum. In vitro study showed that nephrin expressed close to synaptic proteins and demonstrate that nephrin interacts with Fyn kinase, glutamate receptors and the scaffolding molecule PSD95 [84]. However, histological analysis did not reveal any apparent morphological changes in the cerebellum of newborn Nephrin KO mice. The role of Nephrin in brain remains unclear. It has been reported that nearly $10 \%$ of CNF patients have minor neurological abnormalities such as muscular dystonia, ataxia and athetosis. However, these abnormalities may also be a complication of the severe proteinuria or other comorbidities.

\subsection{Pancreas}

In the pancreas, Nephrin expression is localized to the insu- lin-producing cells of the islets of Langerhans [13,85], beta cells [85] and islet microendothelia [86]. Although the exact function of Nephrin in pancreas is still unknown, it may serve as a structural protein in islet microendothelium [86]. Glucose levels and insulin secretion are normal in CNF patients as assessed by OGTT test [87].

\subsection{Testis}

Nephrin is also expressed in Sertoli cells of the mouse testis [88]. Sertoli cells provide mechanical support, protection and nutrition to the developing germ cells, and formation of the blood-testis barrier. Nephrin seems to have an important role in these functions. Nephrin KO male mice were infertile, with undescended testicles and impaired seminal vesicle formation. Abnormal pubertal development and testicular function have also been reported in male CNF patients [87] .

\subsection{Lymphoid tissue}

Nephrin can be found in the spleen of the rat [8]. Aström et al. [89] demonstrated Nephrin expression in human tonsil, adenoid and lymph node. Nephrin-positive cells were detected in the germinal centers of the lymphoid follicles in a staining pattern typical for dentritic cells. Dendritic cells maintain the framework in the lymphoid follicle and offer a stable network for proliferation and differentiation of $\mathrm{B}$ lymphocytes [90]. Therefore, Nephrin may act as a cell junction adhesion molecule in lymphoid tissue, similarly to its function in the SD.

\subsection{Heart}

Nephrin is also required for cardiovascular development. Nephrin is expressed in the epicardium and coronary vessels during human and mouse embryonic development. Nephrin KO showed abnormal epicardial cell morphology and a reduced number of coronary vessels, and cardiac fibrosis [91].

\section{Conclusion}

Taken together, Nephrin is a key scaffolding protein in po- 


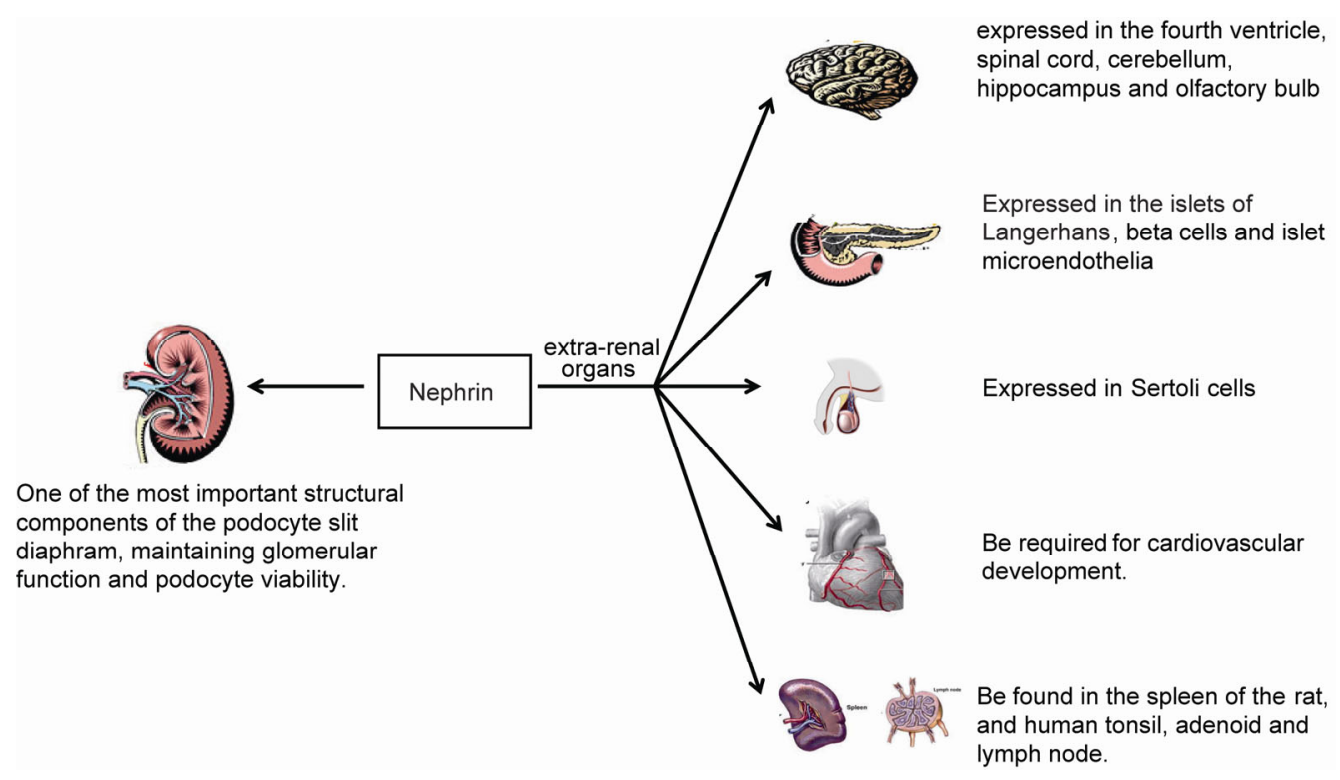

Figure 3 Nephrin in different organs.

docyte SD. Nephrin is required for maintaining SD integrity and SD-mediated signaling to preserve glomerular function and podocyte viability. Reduced expression or abnormal distribution of Nephrin has been observed in many glomerular diseases. Future studies are required to confirm whether Nephrin expression could be used as a biomarker for prediction of the progression of glomerular disease or Nephrin could be developed as a potential drug target for treatment of glomerular disease. In addition, it would be interesting to further explore the function of Nephrin outside of the kidney.

1 Kestila M, Lenkkeri U, Mannikko M, Lamerdin J, McCready P, Putaala H, Ruotsalainen V, Morita T, Nissinen M, Herva R, Kashtan CE, Peltonen L, Holmberg C, Olsen A, Tryggvason K. Positionally cloned gene for a novel glomerular protein - nephrin - is mutated in congenital nephrotic syndrome. Mol Cell 1998, 1: 575-582

2 Lenkkeri U, Mannikko M, McCready P, Lamerdin J, Gribouval O, Niaudet PM, Antignac CK, Kashtan CE, Homberg C, Olsen A, Kestila M, Tryggvason K. Structure of the gene for congenital nephrotic syndrome of the finnish type (NPHS1) and characterization of mutations. Am J Hum Genet, 1999, 64: 51-61

3 Grahammer F, Schell C, Huber TB. The podocyte slit diaphragm--from a thin grey line to a complex signalling hub. Nat Rev Nephrol, 2013, 9: 587-598

4 Brummendorf T, Rathjen FG. Cell adhesion molecules 1: immunoglobulin superfamily. Protein Profile, 1995, 2: 963-1108

5 Chothia C, Jones EY. The molecular structure of cell adhesion molecules. Annu Rev Biochem, 1997, 66: 823-862

6 Fahrig T, Landa C, Pesheva P, Kuhn K, Schachner M. Characterization of binding properties of the myelin-associated glycoprotein to extracellular matrix constituents. EMBO J, 1987, 6: 2875-2883

7 Tryggvason K. Unraveling the mechanisms of glomerular ultrafiltration: nephrin, a key component of the slit diaphragm. J Am Soc Nephrol, 1999, 10: 2440-2445

8 Ahola H, Wang SX, Luimula P, Solin ML, Holzman LB, Holthofer H. Cloning and expression of the rat nephrin homolog. Am J Pathol, 1999, 155: 907-913
9 Topham PS, Kawachi H, Haydar SA, Chugh S, Addona TA, Charron KB, Holzman LB, Shia M, Shimizu F, Salant DJ. Nephritogenic mAb 5-1-6 is directed at the extracellular domain of rat nephrin. J Clin Invest, 1999, 104: 1559-1566

10 Yan K, Khoshnoodi J, Ruotsalainen V, Tryggvason K. N-linked glycosylation is critical for the plasma membrane localization of nephrin. J Am Soc Nephrol, 2002, 13: 1385-1389

11 Luimula P, Aaltonen P, Ahola H, Palmen T, Holthofer H. Alternatively spliced nephrin in experimental glomerular disease of the rat. Pediatr Res, 2000, 48: 759-762

12 Beltcheva O, Kontusaari S, Fetissov S, Putaala H, Kilpelainen P, Hokfelt T, Tryggvason K. Alternatively used promoters and distinct elements direct tissue-specific expression of nephrin. J Am Soc Nephrol, 2003, 14: 352-358

13 Putaala H, Soininen R, Kilpelainen P, Wartiovaara J, Tryggvason K. The murine nephrin gene is specifically expressed in kidney, brain and pancreas: inactivation of the gene leads to massive proteinuria and neonatal death. Hum Mol Genet, 2001, 10: 1-8

14 Ihalmo P, Rinta-Valkama J, Mai P, Astrom E, Palmen T, Pham TT, Floss T, Holthofer H. Molecular cloning and characterization of an endogenous antisense transcript of Nphs1. Genomics, 2004, 83: $1134-1140$

15 Ihalmo P, Palmen T, Ahola H, Valtonen E, Holthofer H. Filtrin is a novel member of nephrin-like proteins. Biochem Biophys Res Commun, 2003, 300: 364-370

16 Ichimura K, Fukuyo Y, Nakamura T, Powell R, Sakai T, Janknecht R, Obara T. Developmental localization of nephrin in zebrafish and medaka pronephric glomerulus. J Histochem Cytochem, 2013, 61: 313-324

17 Casotti G, Braun EJ. Functional morphology of the glomerular filtration barrier of Gallus gallus. J Morphol, 1996, 228: 327-334

18 Volker LA, Petry M, Abdelsabour-Khalaf M, Schweizer H, Yusuf F, Busch T, Schermer B, Benzing T, Brand-Saberi B, Kretz O, Hohne $\mathrm{M}$, Kispert A. Comparative analysis of Neph gene expression in mouse and chicken development. Histochem Cell Biol, 2012, 137: 355-366

19 Done SC, Takemoto M, He L, Sun Y, Hultenby K, Betsholtz C, Tryggvason K. Nephrin is involved in podocyte maturation but not survival during glomerular development. Kidney Int, 2008, 73: 697-704

20 Palmen T, Lehtonen S, Ora A, Kerjaschki D, Antignac C, Lehtonen E, Holthofer H. Interaction of endogenous nephrin and CD2-associated protein in mouse epithelial M-1 cell line. J Am Soc Nephrol, 2002, 
13: 1766-1772

21 Shih NY, Li J, Cotran R, Mundel P, Miner JH, Shaw AS. CD2AP localizes to the slit diaphragm and binds to nephrin via a novel C-terminal domain. Am J Pathol, 2001, 159: 2303-2308

22 Huber TB, Hartleben B, Kim J, Schmidts M, Schermer B, Keil A, Egger L, Lecha RL, Borner C, Pavenstadt H, Shaw AS, Walz G, Benzing T. Nephrin and CD2AP associate with phosphoinositide 3-OH kinase and stimulate AKT-dependent signaling. Mol Cell Biol, 2003, 23: 4917-4928

23 Tossidou I, Niedenthal R, Klaus M, Teng B, Worthmann K, King BL, Peterson KJ, Haller H, Schiffer M. CD2AP regulates SUMOylation of CIN85 in podocytes. Mol Cell Biol, 2012, 32: 1068-1079

24 Tossidou I, Teng B, Drobot L, Meyer-Schwesinger C, Worthmann K, Haller H, Schiffer M. CIN85/RukL is a novel binding partner of nephrin and podocin and mediates slit diaphragm turnover in podocytes. J Biol Chem, 2010, 285: 25285-25295

25 Shih NY, Li J, Karpitskii V, Nguyen A, Dustin ML, Kanagawa O, Miner JH, Shaw AS. Congenital nephrotic syndrome in mice lacking CD2-associated protein. Science, 1999, 286: 312-315

26 Li C, Ruotsalainen V, Tryggvason K, Shaw AS, Miner JH. CD2AP is expressed with nephrin in developing podocytes and is found widely in mature kidney and elsewhere. Am J Physiol Renal Physiol, 2000, 279: F785-792

27 Huber TB, Kottgen M, Schilling B, Walz G, Benzing T. Interaction with podocin facilitates nephrin signaling. J Biol Chem, 2001, 276: 41543-41546

28 Schwarz K, Simons M, Reiser J, Saleem MA, Faul C, Kriz W, Shaw AS, Holzman LB, Mundel P. Podocin, a raft-associated component of the glomerular slit diaphragm, interacts with CD2AP and nephrin. J Clin Invest, 2001, 108: 1621-1629

29 Roselli S, Heidet L, Sich M, Henger A, Kretzler M, Gubler MC, Antignac C. Early glomerular filtration defect and severe renal disease in podocin-deficient mice. Mol Cell Biol, 2004, 24: 550-560

30 Aucella F, De Bonis P, Gatta G, Muscarella LA, Vigilante M, di Giorgio G, D'Errico M, Zelante L, Stallone C, Bisceglia L. Molecular analysis of NPHS2 and ACTN4 genes in a series of 33 Italian patients affected by adult-onset nonfamilial focal segmental glomerulosclerosis. Nephron Clin Pract, 2005, 99: c31-36

31 Serizawa S, Miyamichi K, Takeuchi H, Yamagishi Y, Suzuki M, Sakano H. A neuronal identity code for the odorant receptor-specific and activity-dependent axon sorting. Cell, 2006, 127: 1057-1069

32 Harita Y, Kurihara H, Kosako H, Tezuka T, Sekine T, Igarashi T, Hattori S. Neph1, a component of the kidney slit diaphragm, is tyrosine-phosphorylated by the Src family tyrosine kinase and modulates intracellular signaling by binding to Grb2. J Biol Chem, 2008, 283: 9177-9186

33 Gerke P, Huber TB, Sellin L, Benzing T, Walz G. Homodimerization and heterodimerization of the glomerular podocyte proteins nephrin and NEPH1. J Am Soc Nephrol, 2003, 14: 918-926

34 Barletta GM, Kovari IA, Verma RK, Kerjaschki D, Holzman LB. Nephrin and Neph1 co-localize at the podocyte foot process intercellular junction and form cis hetero-oligomers. J Biol Chem, 2003, 278: 19266-19271

35 Otaki Y, Miyauchi N, Higa M, Takada A, Kuroda T, Gejyo F, Shimizu F, Kawachi H. Dissociation of NEPH1 from nephrin is involved in development of a rat model of focal segmental glomerulosclerosis. Am J Physiol Renal Physiol, 2008, 295: F1376-1387

36 Verma R, Kovari I, Soofi A, Nihalani D, Patrie K, Holzman LB. Nephrin ectodomain engagement results in Src kinase activation, nephrin phosphorylation, Nck recruitment, and actin polymerization. J Clin Invest, 2006, 116: 1346-1359

37 Jones N, Blasutig IM, Eremina V, Ruston JM, Bladt F, Li H, Huang H, Larose L, Li SS, Takano T, Quaggin SE, Pawson T. Nck adaptor proteins link nephrin to the actin cytoskeleton of kidney podocytes. Nature, 2006, 440: 818-823

38 Donoviel DB, Freed DD, Vogel H, Potter DG, Hawkins E, Barrish JP, Mathur BN, Turner CA, Geske R, Montgomery CA, Starbuck M, Brandt M, Gupta A, Ramirez-Solis R, Zambrowicz BP, Powell DR. Proteinuria and perinatal lethality in mice lacking NEPH1, a novel protein with homology to NEPHRIN. Mol Cell Biol, 2001, 21: 4829-4836

39 Sellin L, Huber TB, Gerke P, Quack I, Pavenstadt H, Walz G. NEPH1 defines a novel family of podocin interacting proteins. FASEB J, 2003, 17: 115-117

40 Huber TB, Schmidts M, Gerke P, Schermer B, Zahn A, Hartleben B, Sellin L, Walz G, Benzing T. The carboxyl terminus of Neph family members binds to the PDZ domain protein zonula occludens-1. J Biol Chem, 2003, 278: 13417-13421

41 Gerke P, Sellin L, Kretz O, Petraschka D, Zentgraf H, Benzing T, Walz G. NEPH2 is located at the glomerular slit diaphragm, interacts with nephrin and is cleaved from podocytes by metalloproteinases. J Am Soc Nephrol, 2005, 16: 1693-1702

42 Wang H, Lehtonen S, Chen YC, Heikkila E, Panula P, Holthofer H. Neph3 associates with regulation of glomerular and neural development in zebrafish. Differentiation, 2012, 83: 38-46

43 Rincon-Choles H, Vasylyeva TL, Pergola PE, Bhandari B, Bhandari K, Zhang JH, Wang W, Gorin Y, Barnes JL, Abboud HE. ZO-1 expression and phosphorylation in diabetic nephropathy. Diabetes, 2006, 55: 894-900

44 Reiser J, Kriz W, Kretzler M, Mundel P. The glomerular slit diaphragm is a modified adherens junction. J Am Soc Nephrol, 2000, 11: $1-8$

45 Patrakka J, Kestila M, Wartiovaara J, Ruotsalainen V, Tissari P, Lenkkeri U, Mannikko M, Visapaa I, Holmberg C, Rapola J, Tryggvason K, Jalanko H. Congenital nephrotic syndrome (NPHS1): features resulting from different mutations in Finnish patients. Kidney Int, 2000, 58: 972-980

46 Kaplan JM, Kim SH, North KN, Rennke H, Correia LA, Tong HQ, Mathis BJ, Rodriguez-Perez JC, Allen PG, Beggs AH, Pollak MR. Mutations in ACTN4, encoding alpha-actinin-4, cause familial focal segmental glomerulosclerosis. Nat Genet, 2000, 24: 251-256

47 Michaud JL, Lemieux LI, Dube M, Vanderhyden BC, Robertson SJ, Kennedy CR. Focal and segmental glomerulosclerosis in mice with podocyte-specific expression of mutant alpha-actinin-4. J Am Soc Nephrol, 2003, 14: 1200-1211

48 Fan Q, Xing Y, Ding J, Guan N, Zhang J. The relationship among nephrin, podocin, CD2AP, and alpha-actinin might not be a true 'interaction' in podocyte. Kidney Int, 2006, 69: 1207-1215

49 Faul C, Asanuma K, Yanagida-Asanuma E, Kim K, Mundel P. Actin up: regulation of podocyte structure and function by components of the actin cytoskeleton. Trends Cell Biol, 2007, 17: 428-437

50 New LA, Martin CE, Jones N. Advances in slit diaphragm signaling. Curr Opin Nephrol Hypertens, 2014, 23: 420-430

51 Verma R, Wharram B, Kovari I, Kunkel R, Nihalani D, Wary KK, Wiggins RC, Killen P, Holzman LB. Fyn binds to and phosphorylates the kidney slit diaphragm component Nephrin. J Biol Chem, 2003, 278: 20716-20723

52 New LA, Keyvani Chahi A, Jones N. Direct regulation of nephrin tyrosine phosphorylation by Nck adaptor proteins. J Biol Chem, 2013, 288: $1500-1510$

53 Quack I, Woznowski M, Potthoff SA, Palmer R, Konigshausen E, Sivritas S, Schiffer M, Stegbauer J, Vonend O, Rump LC, Sellin L. PKC alpha mediates beta-arrestin2-dependent nephrin endocytosis in hyperglycemia. J Biol Chem, 2011, 286: 12959-12970

54 Tossidou I, Teng B, Menne J, Shushakova N, Park JK, Becker JU, Modde F, Leitges M, Haller H, Schiffer M. Podocytic PKC-alpha is regulated in murine and human diabetes and mediates nephrin endocytosis. PLoS One, 2010, 5: e10185

55 Satoh D, Hirose T, Harita Y, Daimon C, Harada T, Kurihara H, Yamashita A, Ohno S. aPKClambda maintains the integrity of the glomerular slit diaphragm through trafficking of nephrin to the cell surface. J Biochem, 2014, 156: 115-128

56 Harita Y, Kurihara H, Kosako H, Tezuka T, Sekine T, Igarashi T, Ohsawa I, Ohta S, Hattori S. Phosphorylation of nephrin triggers $\mathrm{Ca}^{2+}$ signaling by recruitment and activation of phospholipase C-\{gamma \}1. J Biol Chem, 2009, 284: 8951-8962

57 Fan X, Li Q, Pisarek-Horowitz A, Rasouly HM, Wang X, Bonegio RG, Wang H, McLaughlin M, Mangos S, Kalluri R, Holzman LB, 
Drummond IA, Brown D, Salant DJ, Lu W. Inhibitory effects of Robo2 on nephrin: a crosstalk between positive and negative signals regulating podocyte structure. Cell Rep, 2012, 2: 52-61

58 Huttunen NP. Congenital nephrotic syndrome of Finnish type. Study of 75 patients. Arch Dis Child, 1976, 51: 344-348

59 Holmberg C, Antikainen M, Ronnholm K, Ala Houhala M, Jalanko H. Management of congenital nephrotic syndrome of the Finnish type. Pediatr Nephrol, 1995, 9: 87-93

60 Kaukinen A, Kuusniemi AM, Helin H, Jalanko H. Changes in glomerular mesangium in kidneys with congenital nephrotic syndrome of the Finnish type. Pediatr Nephrol, 2010, 25: 867-875

61 Patrakka J, Ruotsalainen V, Reponen P, Qvist E, Laine J, Holmberg C, Tryggvason K, Jalanko H. Recurrence of nephrotic syndrome in kidney grafts of patients with congenital nephrotic syndrome of the Finnish type: role of nephrin. Transplantation, 2002, 73: 394-403

62 Wang SX, Ahola H, Palmen T, Solin ML, Luimula P, Holthofer H. Recurrence of nephrotic syndrome after transplantation in CNF is due to autoantibodies to nephrin. Exp Nephrol, 2001, 9: 327-331

63 Fukusumi Y, Miyauchi N, Hashimoto T, Saito A, Kawachi H. Therapeutic target for nephrotic syndrome: identification of novel slit diaphragm associated molecules. World J Nephrol, 2014, 3: 77-84

64 Furness PN, Hall LL, Shaw JA, Pringle JH. Glomerular expression of nephrin is decreased in acquired human nephrotic syndrome. Nephrol Dial Transplant, 1999, 14: 1234-1237

65 Hulkko J, Patrakka J, Lal M, Tryggvason K, Hultenby K, Wernerson A. Neph1 is reduced in primary focal segmental glomerulosclerosis, minimal change nephrotic syndrome, and corresponding experimental animal models of adriamycin-induced nephropathy and puromycin aminonucleoside nephrosis. Nephron Extra, 2014, 4: $146-154$

66 Huh W, Kim DJ, Kim MK, Kim YG, Oh HY, Ruotsalainen V, Tryggvason K. Expression of nephrin in acquired human glomerular disease. Nephrol Dial Transplant, 2002, 17: 478-484

67 Kawachi H, Koike H, Kurihara H, Yaoita E, Orikasa M, Shia MA, Sakai T, Yamamoto T, Salant DJ, Shimizu F. Cloning of rat nephrin: expression in developing glomeruli and in proteinuric states. Kidney Int, 2000, 57: 1949-1961

68 Benigni A, Tomasoni S, Gagliardini E, Zoja C, Grunkemeyer JA, Kalluri R, Remuzzi G. Blocking angiotensin II synthesis/activity preserves glomerular nephrin in rats with severe nephrosis. J Am Soc Nephrol, 2001, 12: 941-948

69 Luimula P, Ahola H, Wang SX, Solin ML, Aaltonen P, Tikkanen I, Kerjaschki D, Holthofer H. Nephrin in experimental glomerular disease. Kidney Int, 2000, 58: 1461-1468

70 Zhu B, Li XF, Zhu XL, Lin Y, Zhong S, Zhu CF, Tang XL, Hu YQ, Cheng XX, Wang YJ. ELISA analysis of urinary nephrin and podocalyxin standardized by aquaporin-2 in adult patients with nephrotic syndrome. J Nephrol, 2014, 27: 411-417

71 Patrakka J, Ruotsalainen V, Ketola I, Holmberg C, Heikinheimo M, Tryggvason K, Jalanko H. Expression of nephrin in pediatric kidney diseases. J Am Soc Nephrol, 2001, 12: 289-296

72 Aaltonen P, Luimula P, Astrom E, Palmen T, Gronholm T, Palojoki E, Jaakkola I, Ahola H, Tikkanen I, Holthofer H. Changes in the expression of nephrin gene and protein in experimental diabetic nephropathy. Lab Invest, 2001, 81: 1185-1190

73 Bonnet F, Cooper ME, Kawachi H, Allen TJ, Boner G, Cao Z. Irbesartan normalises the deficiency in glomerular nephrin expression in a model of diabetes and hypertension. Diabetologia, 2001, 44: 874-877

74 Langham RG, Kelly DJ, Cox AJ, Thomson NM, Holthofer H, Zaoui P, Pinel N, Cordonnier DJ, Gilbert RE. Proteinuria and the expression of the podocyte slit diaphragm protein, nephrin, in diabetic nephropathy: effects of angiotensin converting enzyme inhibition. Diabetolo- gia, 2002, 45: 1572-1576

75 Koop K, Eikmans M, Baelde HJ, Kawachi H, De Heer E, Paul LC, Bruijn JA. Expression of podocyte-associated molecules in acquired human kidney diseases. J Am Soc Nephrol, 2003, 14: 2063-2071

76 Doublier S, Salvidio G, Lupia E, Ruotsalainen V, Verzola D, Deferrari G, Camussi G. Nephrin expression is reduced in human diabetic nephropathy: evidence for a distinct role for glycated albumin and angiotensin II. Diabetes, 2003, 52: 1023-1030

77 Benigni A, Gagliardini E, Tomasoni S, Abbate M, Ruggenenti P, Kalluri R, Remuzzi G. Selective impairment of gene expression and assembly of nephrin in human diabetic nephropathy. Kidney Int, 2004, 65: 2193-2200

78 Perysinaki GS, Moysiadis DK, Bertsias G, Giannopoulou I, Kyriacou K, Nakopoulou L, Boumpas DT, Daphnis E. Podocyte main slit diaphragm proteins, nephrin and podocin, are affected at early stages of lupus nephritis and correlate with disease histology. Lupus, 2011, 20: 781-791

79 Oranskiy SP, Yeliseyeva LN. Urinary excretion of nephrin in rheumatoid arthritis patients with proteinuria. Clin Exp Rheumatol, 2014, 32: $572-574$

80 Juhila J, Lassila M, Roozendaal R, Lehtonen E, Messing M, Langer B, Kerjaschki D, Verbeek JS, Holthofer H. Inducible nephrin transgene expression in podocytes rescues nephrin-deficient mice from perinatal death. Am J Pathol, 2010, 176: 51-63

81 Rantanen M, Palmen T, Patari A, Ahola H, Lehtonen S, Astrom E, Floss T, Vauti F, Wurst W, Ruiz P, Kerjaschki D, Holthofer H. Nephrin TRAP mice lack slit diaphragms and show fibrotic glomeruli and cystic tubular lesions. J Am Soc Nephrol, 2002, 13: 1586-1594

82 Orikasa M, Matsui K, Oite T, Shimizu F. Massive proteinuria induced in rats by a single intravenous injection of a monoclonal antibody. J Immunol, 1988, 141: 807-814

83 Li X, Chuang PY, D'Agati VD, Dai Y, Yacoub R, Fu J, Xu J, Taku O, Premsrirut PK, Holzman LB, He JC. Nephrin Preserves Podocyte Viability and Glomerular Structure and Function in Adult Kidneys. J Am Soc Nephrol, 2015, pii: JASN.2014040405

84 Li M, Armelloni S, Ikehata M, Corbelli A, Pesaresi M, Calvaresi N, Giardino L, Mattinzoli D, Nistico F, Andreoni S, Puliti A, Ravazzolo R, Forloni G, Messa P, Rastaldi MP. Nephrin expression in adult rodent central nervous system and its interaction with glutamate receptors. J Pathol, 2011, 225: 118-128

85 Palmen T, Ahola H, Palgi J, Aaltonen P, Luimula P, Wang S, Jaakkola I, Knip M, Otonkoski T, Holthofer H. Nephrin is expressed in the pancreatic beta cells. Diabetologia, 2001, 44: 1274-1280

86 Zanone MM, Favaro E, Doublier S, Lozanoska-Ochser B, Deregibus MC, Greening J, Huang GC, Klein N, Cavallo Perin P, Peakman M, Camussi G. Expression of nephrin by human pancreatic islet endothelial cells. Diabetologia, 2005, 48: 1789-1797

87 Kuusniemi AM, Kestila M, Patrakka J, Lahdenkari AT, Ruotsalainen V, Holmberg C, Karikoski R, Salonen R, Tryggvason K, Jalanko H. Tissue expression of nephrin in human and pig. Pediatr Res, 2004, 55: 774-781

88 Liu L, Aya K, Tanaka H, Shimizu J, Ito S, Seino Y. Nephrin is an important component of the barrier system in the testis. Acta Med Okayama, 2001, 55: 161-165

89 Astrom E, Rinta-Valkama J, Gylling M, Ahola H, Miettinen A, Timonen T, Holthofer H. Nephrin in human lymphoid tissues. Cell Mol Life Sci, 2006, 63: 498-504

90 Kroese FG, Wubbena AS, Seijen HG, Nieuwenhuis P. Germinal centers develop oligoclonally. Eur J Immunol, 1987, 17: 1069-1072

91 Wagner N, Morrison H, Pagnotta S, Michiels JF, Schwab Y, Tryggvason K, Schedl A, Wagner KD. The podocyte protein nephrin is required for cardiac vessel formation. Hum Mol Genet, 2011, 20: 2182-2194

Open Access This article is distributed under the terms of the Creative Commons Attribution License which permits any use, distribution, and reproduction in any medium, provided the original author(s) and source are credited. 